\title{
A Comparison of the Effects of Gama Sterilisation and Ethylen Oxide Sterilisation Over the Bio-Compatibility of Polymeric Biomaterials
}

\author{
Gama Sterilizasyon ve Etilen Oksit Sterilizasyonunun \\ Polimerik Biyomalzemelerin Biyo-Uyumluluğu Üzerine \\ Etkilerinin Karşılaștırılması
}

Faik Türkmen, Uğur Yensen

Selcuk University Meram Medical Faculty Orthopedics and Traumatology Department Konya, Turkey

Eur J Basic Med Sci 2011;1(1):1-6

Received: 31.08 .2010

Accepted: 27.09 .2010

Correspondence (Yazıșma Adresi): Faik Türkmen

Mevlana Üniversitesi Tıp Fakültesi Konya Hastanesi Ortopedi ve Travmatoloji

Bölümü, Konya

Tel: 905333841204

E-mail: ft.faikturkmen@gmail.com

\begin{abstract}
Bio-materials have find a very large area of utilization in medicine. Bio-compatibility is one of the important characteristics of bio-materials. In vivo and in vitro protocols can be implemented in research on bio-compatibility. The present research was conducted for the purpose of comparing the effects of gamma sterilization and ethylene oxide sterilization on bio-compatibility of various polymeric bio-materials. In this research, we used the technique of implantation on animals, which is one of the in vivo protocols, and we investigated different histological parameters utilizing sterilization techniques. A total of 180 ultra-high molecular weight polyethylene (UHMWPE), silicone, teflon, delrin and carbon fiber materials, whose bio-compatibility should be investigated, were prepared in the size of $1 \times 1 \mathrm{~cm}$ in equal numbers from each. 90 of the materials, were sterilised with the gamma sterilisation technique whereas the remaining 90 were sterilised using ethylene oxide gas. Then, these materials were implanted on rats using appropriate techniques and histological and microbiological studies were conducted. As a result, we did not isolate microorganisms in either sterilization technique in samples that were examined after sterilization and we observed that both techniques had similar effects in terms of sterilization. However, it was observed that the sterilization technique that was implemented had an effect on bio-compatibility and that gamma sterilization was more compatible than ethylene oxide in terms of bio-compatibility. In performing microbiological examination, microorganisms were not isolated in either sterilization method and a similar effect for sterilization was observed in this research.
\end{abstract}

Key words: Bio-materials, bio-compatible, gamma sterilization, ethylene oxide sterilization 
ÖZET

Biyo-materyaller tıpta çok geniş kullanım alanı bulmuş olan malzemelerdir. Biyo-uyumluluk, biyo-materyalin sahip olması gereken en önemli özelliklerdendir. Biyo-uyumluluğun araștırılmasında in vivo ve in vitro protokoller uygulanabilmektedir. Bu araștırma, çeșitli polimerik biyo-malzemelerin biyouyumluluğu üzerine gama sterilizasyonla etilen oksit sterilizasyon uygulamalarının etkilerinin karșılaștırılması amacıyla yapılmıștır. Bu araștırmada, in vivo protokollerden biri olan canlıya implantasyon tekniğini kullanılarak çeșitli histolojik parametreler kullanılmıștır. Biyo-uyumlulukları araștırılacak olan, çok yüksek molekül ağırlıklı polietilen (UHMWPE), silikon, teflon, delrin ve karbon fiber malzemeler $1 \times 1 \mathrm{~cm}$. boyutlarında, her birinden eșit sayıda olmak üzere, 180 adet hazırlanmıștır. Kendi içlerinde guruplandırılmış materyallerin 90 tanesi gama sterilizasyon yöntemi ile, 90 tanesi de etilen oksit gazı ile sterilize edilmiștir. Daha sonra bu materyaller uygun teknikler kullanılarak, ratlara implante edilmiștir. Histolojik ve mikrobiyolojik araștırmalar yapılmıștır. Sonuç olarak, her iki sterilizasyon yönteminde de, sterilizasyon sonrası incelenen örneklerde mikroorganizma izole edilmemiştir ve bu araștırmada sterilizasyon açısından her iki yöntemin benzer etkinliğe sahip oldukları gözlemlenmiștir. Bununla birlikte, uygulanan sterilizasyon yönteminin biyo-uyumluluk üzerinde etkisinin olduğu ve gama sterilizasyonun etilen oksit ile yapılan sterilizasyonundan biyo-uyumluluk açısından daha uyumlu olduğunu gözlemlenmiștir.

Anahtar kelimeler: Biyo-materyaller, Biyo-uyumluluk, gama sterilizasyon, etilen oksit sterilizasyonu

\section{INTRODUCTION}

Bio-materials are natural or synthetic materials that are used for tissues in a live body to perform or support their functions $(1,2)$. Bio-materials found a significant area of use especially in orthopedics in paralell to the developments in surgery and their in vivo use has progressed rapidly since the 1900 s(3). Bio-materials are used extensively ranging from suture materials to joint prostheses.

Bio-compatibility is the ability of the material to respond to live tissues during and after the implementation(4). The most important characteristic that is required of biomaterials is their bio-compatibility $(4,5)$. Sterilisation of these materials should be easy to perform(6). They should not lead to irreversible changes in blood cells and proteins. They should not activate the immune system ir- reversibly $(4,6)$. There is no bio-material that is a hundred per cent bio-compatible but the reaction against these materials should be remain within tolerable limits (7).

In research on bio-compatibility, in vivo intramuscular implantation and histopathological examination of the reaction that occurred are among the methods that are used. No matter which of these implantation techniques are used, criteria for histopathological examination such as investigation of infected cells, measurement of the thickness of fibrous membrane, necrosis that occurred in the surrounding tissues, the vascularisation characteristics, the content of the membrane cell that formed and investigation of fat infiltration around are taken into consideration(8).

The present study aims at comparing the effects of gamma sterilisation and ethylene oxide sterilisation on biocompatibility of various polymeric bio-materials.

\section{MATERIALS AND METHODS}

This research was conducted in the Experimental Research Centre at Selcuk University Meram Medical Faculty. 180 female Sprague-Dawley rats whose average weights were between 200 and 250 gr were used in the study. The equal number of ultra-high molecular weight polyethylene (UHMWPE), silicone, teflon, delrin and carbon fiber materials, whose bio-compatibility would be investigated, were prepared total $1801 \times 1 \mathrm{~cm}$ pieces. 90 of these materials were sterilised with the gamma sterilisiation method and the remaining 90 were sterilised using ethylene oxide.

The rats were first divided into two groups, namely group A and B. Those in group A were implanted with materials that were sterilised with gamma sterilisation whereas those in group B were implanted with materials that were sterilised using ethylene oxide. Thus, each group was implanted with 18 pieces from each material. In both groups, subgroups containing 18 rats were constituted and thus a total of 10 subgroups were formed. The rats were kept in metal cages at normal room temparature, fed with standard rat feed and water and observed.

All the rats included in the study were administered 5 $\mathrm{mg} / \mathrm{kg}$ ketamine hydrochloride intramuscularly to anesthetise them. After the administration of the anesthetic agent, the backs of the rats were shaved without caus- 


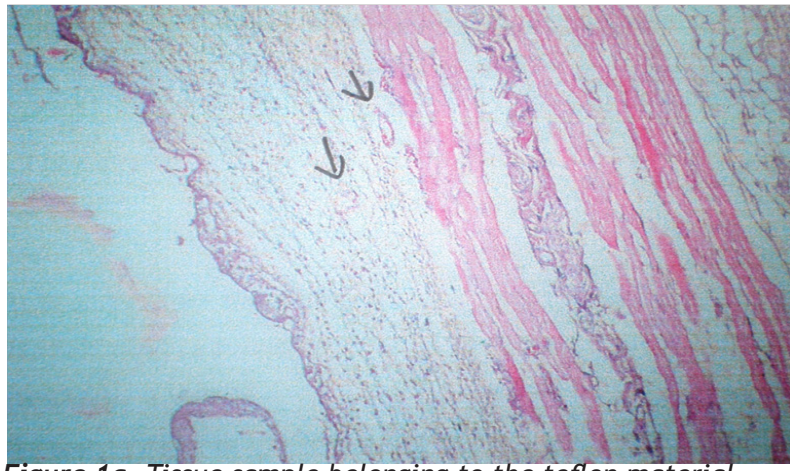

Figure 1a. Tissue sample belonging to the teflon material sterilised with ethylene oxide.

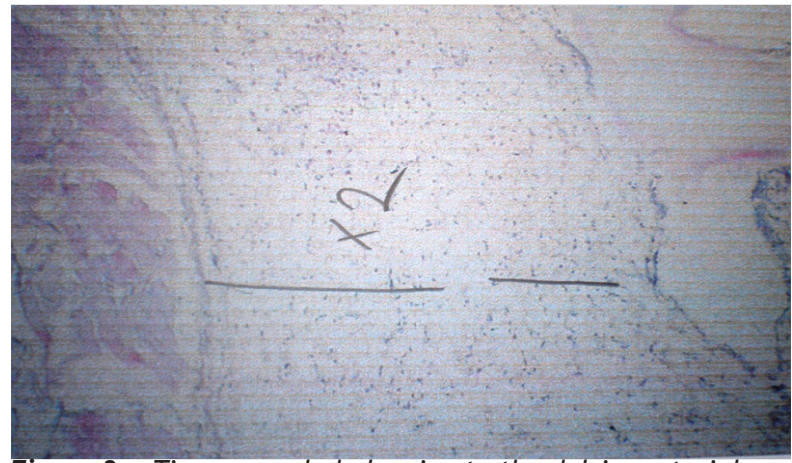

Figure 3a. Tissue sample belonging to the delrin material sterilised with ethylene oxide.

ing damage to the skin. Then, this area was sterilised with povidon iodine. An incision of $1,5-2 \mathrm{~cm}$. was taken right from the middle of the back and thus the skin and subcutan tissues were crossed. A pouch was formed in paravertebral muscles. The skin was sutured with $4 / 0$ atraumatic silk after the material was placed in the pouch.

From the 3rd day on after the implantation, one-third (six rats) of the implants in each of the 10 subgroups were removed together with the surrounding tissues, biopsies were taken and the rats were sacrificed by being given high doses of anesthetic agent. Samples were taken from each implant for the purpose of microbiological studies, put into culture tubes and evaluated in terms of microorganisms. All these procedures were conducted in sterilised conditions. The materials and the surrounding tissues to be sent to the pathology laboratory were put in $10 \%$ formaline and submitted to the laboratory. The same procedure was repeated same number on the 7 th and 21st days.

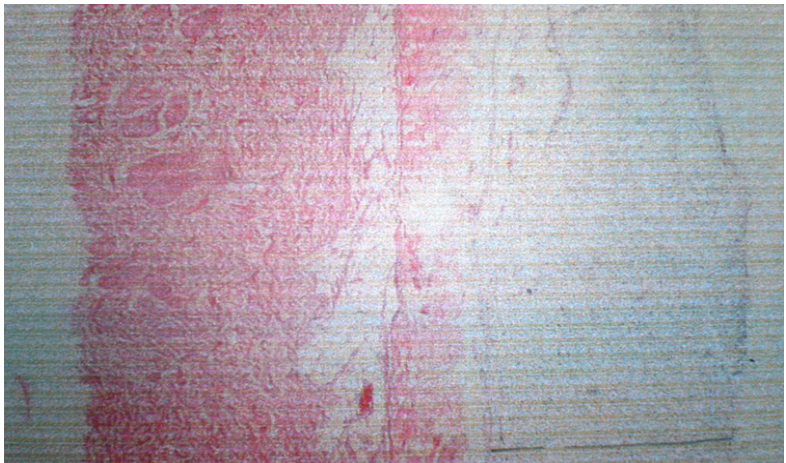

Figure $1 \mathrm{~b}$. Tissue sample belonging to the teflon material sterilised with gamma sterilisation.

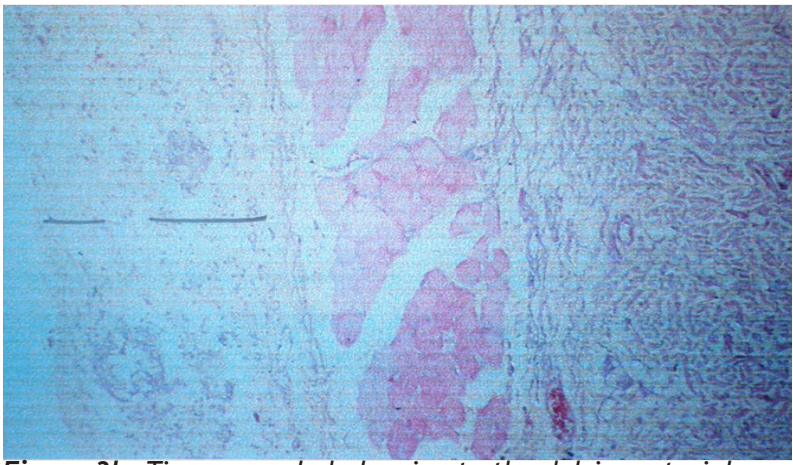

Figure $3 \mathrm{~b}$. Tissue sample belonging to the delrin material sterilised with gamma sterilisation

The tissues that were fixed in $10 \%$ formaline were embedded in paraffin blocks after suitable sections were taken and monitored routinely in autotechnicon in the Pathology Department at Selcuk University Meram Medical Faculty. Sections of 5 micron in size were taken using the microtome device and stained with hemotoxylin eosine. These sections were examined under light microscope (Olimpus BH-2). Necrosis in the surrounding tissues, inflammation, thickness of near and far reactional tissues, number of eosinophils, fibroblasts and veins were investigated. EMB agar and bloody agar cultures of microbiological samples were taken and observed in terms of microorganism growth. The samples were considered to be sterilised if no traces of microorganism growth were observed under enlarging lens within 72 hours.

Two-way variance analysis technique was used in order to reveal statistically the effects of sterilisation, material and time factors on parametres. For a comparison of the time factors in each group, Kruskal-Wallis and Mann- 


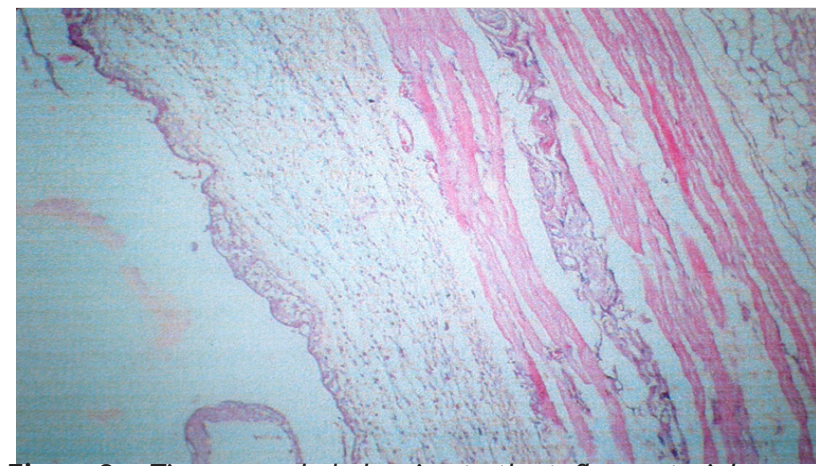

Figure 2a. Tissue sample belonging to the teflon material sterilised with ethylene oxide.

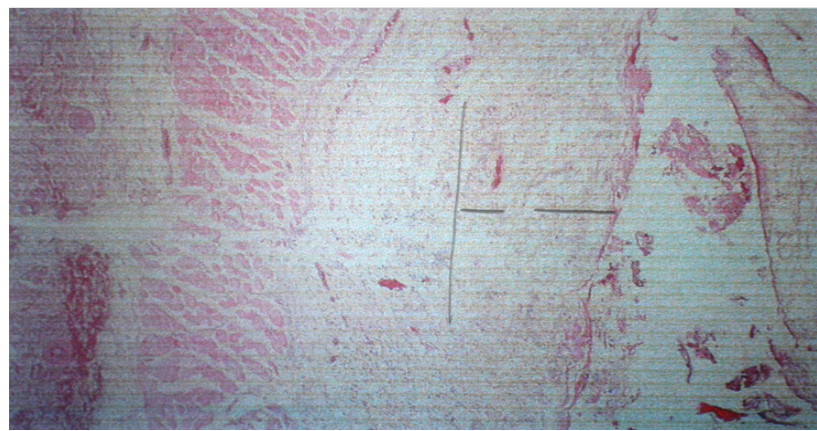

Figure $4 a$. Tissue sample belonging to the polyethylene material sterilised with ethylene oxide.

Whitney-U tests, which are non-parametric tests, were used. Again, for a comparison of the materials in each time group, non-parametric Kruskal-Wallis and MannWhitney-U tests were used. In all tests, if $p<0,05$, the result was considered to be significant.

\section{RESULTS}

IThe changes that five different materials sterilised through the gamma sterilisation technique and ethylene oxide sterilisation technique caused in the surrounding live tissues at the end of certain time periods were investigated. In this study, it was found that the sterilisation method and time factors alone had a significant effect on the number of veins $(p<0,05)$. It was observed that the materials sterilised with ethylene oxide increased the number of veins more than the materials sterilised with the gamma sterilisation technique (Picture $1 \mathrm{a}, \mathrm{b}$.$) . The total number of veins was$ the highest on the 7th day. It was found that for these materials that were studied, the material alone did not

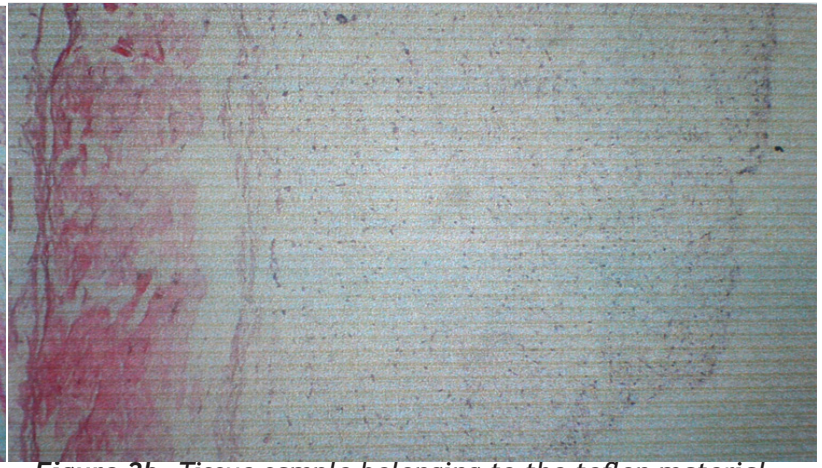

Figure $2 \mathrm{~b}$. Tissue sample belonging to the teflon material sterilised with gamma sterilisation.

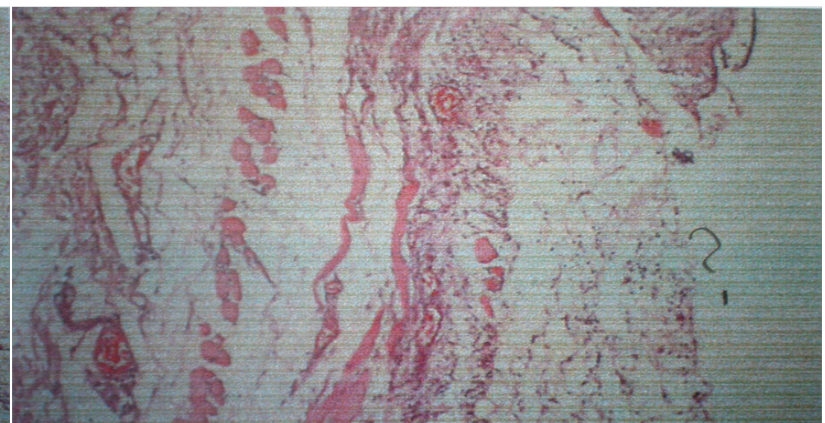

Figure $4 \mathrm{~b}$. Tissue sample belonging to the polyethylene material sterilised with gamma sterilisation.

have a significant effect on the number of veins. It was observed that the sterilisation method and time alone had a significant effect on the number of fibroblasts $(p<0,05)$, and that ethylene oxide increased the number of fibroblasts more than gamma sterilisation (Picture $2 a, b)$; it was found that the total number of fibroblasts was the highest on the 7th day. It was observed that the material alone did not have a significant effect on the number of fibroblasts.

It was found that far reactional tissue thickness that formed around the materials sterilised with ethylene oxide was greater than those sterilised with gamma sterilisation (Picture $3 a, b)$ and this was statistically significant $(p<0,05)$. It was found that near reactional tissue thickness that formed around the materials sterilised with ethylene oxide was greater than those sterilised with gamma sterilisation (Picture 4a,b) and statistically significant $(p<0,05)$. It was observed that near reactinal tissue thickness was the greatest on the 7th day. It was found that material and time factors alone had a significant effect on the number of eosinophils 
$(p<0,05)$, but the method of sterilisation did not have a significant effect $(p=0,652)$. The highest number of eosinophils around the material was on the 7th day. It was observed that the time factor alone had a significant effect on inflammation and the most intensive inflammation was on the 7th day. All the samples were analysed microbiologically and microorganisms were not isolated in any sample as a result of culture.

\section{DISCUSSION}

Surface compatibility is physical, chemical and biological compatibility of the bio-material with the body tissues. Structural compatibility, on the other hand, is compatibility of the bio-material with the mechanical behaviour of the body tissues(3). In 1977, National Heart, Lung and Blood Institute, considering the developments in bio-materials, emphasised that the relationship between blood and material should be studied more painstakingly(4).

In the early 1990s, The International Union for Pure and Applied Chemistiy (IUPAC) established a sub-unit intended to deal with the subject of "Interactions of Polymers with the Living Systems"(4). This unit conducted a series of studies in laboratories in different places across the world and this study was divided into three sub groups, namely the relationship of materials with blood (in vitro studies), bio-compatibility and inflammation, and in vivo studies(4). It can be seen from a review of the relevant literature that all of the studies that have been conducted can be subsumed under these three titles.

Anderson et al(9) investigated the cytotoxic effect of Al-Cu-Fe/UHMWPE composite and UHMWPE on rats in in vitro conditions and found that neither was cytotoxic and equal to one another in terms of cytotoxicity. Van der Kamp et al.(10), in an in vitro study that they conducted, compared how glass, high density polyethylene (HDPE), teflon (PTFE) and silicone activated the coagulation system. As a result, they observed that HDPE activated Factor XIIf and kallikrein the least via contact activation and they concluded that among the samples that they investigated this material was the one that was best compatible with blood.

When a material gets into contact with blood, the first biological molecules that are identified on the surface of the material are proteins(11). On the other hand, the proteins that are first adsorbed to the surface of the material are fibrinogens, fibronectines and immunoglobulines. Leukocytes and platelets perceive these proteins as specific receptors and therefore develop a reaction against the material. In other words, what invites leukocytes and platelets to the material are proteins that belong to the body. In 1990, Ziatz et al.(12) compared the protein adsorption rates of silicone, LDPE and dacron. They investigated Factor XII, Von Willebrand factor, fibrinogene, lg $\mathrm{G}$, albumin, fibronectine and hemoglobin adsorptions. They reported that the material that caused the highest amount of protein adsorption on the surface of the materials is dacron.

Polypropylene fumorate-co-ethylene glycol are used as injectable cardiovascular implants(13). Suggs et al.(13) conducted both in vitro and in vivo studies concerning this material. In the in vitro study, endothelial cell cultures were used in order to evaluate the cytotoxicity of the material. On the other hand, the method of implantation on animal (in vivo implantation) was used in the in vivo component of the same study. Bio-materials cause various inflammatory and recuperative reactions in places in the body where they are implanted(4). This is in the form of a reaction that the body demonstrates against the alien object. How bio-materials activate the complement system, inflammation and cell activations, and their stimulation of cellular reaction have been studied in various forms. Sevastinov et al.(14) found that silicone activates the complement system more than LDPE(Low Density Polyethylen).

Miller et al.(15) investigated whether silicone and LDPE increased in vitro monocyte activation and IL1 production and found that LDPE better activated monocytes and increased IL production more. Bardenave et al.(16) investigated cytocompatibility of some bio-materials in human umbilical and endothelial cell cultures. At the end of the 10-day research period, they found the multiplication speed of the endothelial cells in the culture good. Anderson et al.(17) implanted bio-materials on animals using the cage implant system. They investigated the leukocytes on the surface materials qualitatively and quantitatively. They observed how the materials induced acute and chronic inflammation.

The bio-compatibility of delrin, which is a thermo-plastic polymer and is used as a component of some total hip prostheses thanks to its high mechanical endurance, was investigated by Fister et al.(8) in the form of various protocols. Rats, rabbits and dogs were used in the 
study. Delrin and stainless steel, which were made into small cylinders, were implanted around paravertebral muscles and femurs of these guinea pigs. Existence of inflammation, thickness of the fibrous membrane, cellular content of the membrane, existence of necrosis, blood veins, PMNL, foreign debris and fat infiltration in the surrounding tissues were investigated under light microscope. At the end of an analysis of all the findings that were obtained in this study, it was observed that among the histopathological parametres that were examined, the time period when the number of veins, the number of fibroblasts, thickness of the near reactional tissue, and the number of eosinophils were the highest was the 7th day. This is in conformity with the normal progress of the inflammation. The highest necrosis was determined on the 3rd day in this study.

It was observed that the method of sterilisation had a significant effect on some of the histopathological parametres. It was found that the number of veins, the number of fibroblasts and the thickness of near and far reactional tissues in the tissues around the materials that were sterilised with ethylene oxide were significantly higher than those in the tissues around the materials that were sterilised with gamma sterilisation. This indicates that the method of sterilisation is an effective factor on bio-compatibility. New methods can be implemented in order to investigate biological and physicochemical properties of bio-materials and improve their bio-compatibility. Invention of different bio-materials and their use in human body depend on these new methods. Joint use of in vitro and in vivo protocols is bound to increase chances of success in the investigation of bio-compatibility. Collaboration among medicine, biomaterial science, bio-medical engineering and tissue engineering may contribute to rapid progress in the use of bio-materials in medicine .

\section{REFERENCES}

1. Baretos JW, Eden M. Contemporary Biomaterials. Noyes, Park Ridges, NJ, 1984.

2. Szycher M. High Performance Biomaterials. Technicom, Zurich, 1991.

3. Gümüșderelioğlu M. Biomalzemeler. Bilim ve Teknik Dergisi, Temmuz, 2002.

4. Belanger MC, Marois Y. Hemocompatibility, biocompatibility, inflammatory and in vivo studies of primary reference materials low-density polyethylene and polydimethylsiloxone: A review. J Biomed Mater Res 2001; 58:467-77.

5. Williams DF. Fundamental aspects of biocompatibility. CRC press. Boca Raton, Florida 1981.

6. Ashar BV. Characterization and testing of biomaterials and medical devices. MD\&DI. 1987; January: 57-63.

7. Anderson JM. In vivo biocompatibility of implantable delivery systems and biomaterials. Eur J Pharm Biopharm 1994; 40: 1-8.

8. Fister JS, Memoli VA, Galante JO, Rostoker W, Urban RM. Biocompatibility of delrin 150: A creepresistant polymer for total joint prostheses. J Biomed Mater Res 1985; 19: 519-33.

9. Anderson $B C$, Bloom $P D$, Bakerikar $K G$, Sheares $V V$, Mallapragade SK. Al-Cu-Fe quasicrystal/ultra-high molecular weight polyethylene composites as biomaterials for acetabular cup prosthetics. Biomater 2002;23:1761-68.

10. Van der Kamp KW, Van Oeveren W. Factor XII fragment and kallikrein generation in plasma during incunation with biomaterials. J Biomed Mater Res 1994;28: 349-52.

11. Vroman L. The life of an artificial device in contact with blood. Initial events and their effect on final state. Bull NY Acad Med 1988; 64:352-7.

12. Ziats NP, Pankowsky DA, Tierney BP, Ratnoff $O D$, Anderson JM. Adsorption of Hageman factor (factor XII) and other human plasma proteins to biomedical polymers. J Lab Clin Med 1990; 116: 687-96.

13. Suggs LJ. In vitro cytotoxicity and in vivo biocompatibility of poly (propylen fumarate-co-ethylene glycol) hydrogels. J Biomed Mater Res 1999; 46:22-32.

14. Sevastianov VI, Tseytlina EA, Volkov AV, Shumakov VI. Importance of adsorption-desorption processes of plasma proteins in biomaterial hemocompatibility. Trans Am Soc Artif Intern Organs 1984;30: 137-42.

15. Miller KM, Anderson JM. Human monocyte/macrophage activation and Interleukin I generation by biomedical polymers. J Biomed Mater Res 1988;22: 713-31.

16. Bardenave L, Bareille R, Lefebure F, Caix J, Baqucy C. Cytocompatibility study of NHLBI primary reference materials using endothelial cells. J Biomater Sci Polym Ed 1992;3: 509-16.

17. Spilizewski KL, Marchant RE, Anderson JM, Hiltner A. In vivo leucocyte interactions with the NHLBI-DTB primary reference materials: polyethylene and silica- free polydimethylsiloxane. Biomater 1987;8: 12-7. 